University of Nebraska - Lincoln

DigitalCommons@University of Nebraska - Lincoln

June 2003

\title{
The Match between CEO and Firm
}

SAM ALLGOOD

University of Nebraska - Lincoln, SALLGOOD1@UNL.EDU

Kathleen A. Farrell

University of Nebraska Lincoln, kfarrell2@unl.edu

Follow this and additional works at: https://digitalcommons.unl.edu/cbafacpub

Part of the Business Commons

ALLGOOD, SAM and Farrell, Kathleen A., "The Match between CEO and Firm" (2003). College of Business Faculty Publications. 3.

https://digitalcommons.unl.edu/cbafacpub/3

This Article is brought to you for free and open access by the Business, College of at DigitalCommons@University of Nebraska - Lincoln. It has been accepted for inclusion in College of Business Faculty Publications by an authorized administrator of DigitalCommons@University of Nebraska - Lincoln. 


\section{Sam Allgood \\ Kathleen A. Farrell}

University of Nebraska-Lincoln

\section{The Match between CEO and Firm*}

\section{Introduction}

In December 1999, Douglas Ivester stepped down as CEO of Coca-Cola after serving only 2 years at the helm. The question posed in the Wall Street Journal was, "So fast?" (McKay and Deogun 1999, p. B1). The same question could have been asked 3 months later when Mattel dismissed Jill Barad after she had been its CEO for only 3 years (Lublin and Bannon 2000). These are just two highly publicized examples of a somewhat surprising empirical regularity: a substantial percentage of CEO turnovers occur in the first few years of the CEO's tenure (e.g., Sebora 1996; Allgood and Farrell 2000). These early turnovers are surprising because evidence suggests that, in a given year, the likelihood of CEO turnover is very low (e.g., Warner, Watts, and Wruck 1988; Weisbach 1988; Parrino 1997). In addition, CEO turnover can be a traumatic event for a firm, making the choice of CEO one of the most important hiring decisions the firm makes (Kesner and Sebora 1994).

Sebora (1996) finds that $34 \%$ of all CEO tenures in his sample ended by the CEO's fourth year. Job match theory can provide an explanation of why many CEOs leave their positions within a few years of assuming

\footnotetext{
* We appreciate the helpful comments and suggestions from an anonymous referee, Albert Madansky (editor), Kim Marie McGoldrick, Colin Ramsay, and seminar participants at the Southern Economic Association Meetings and the University of $\mathrm{Ne}$ braska-Lincoln. Kathleen Farrell appreciates receiving partial support from the 1999 Hicks Foundation Summer Research Grant. We are responsible for all errors in the manuscript.
}

(Journal of Business, 2003, vol. 76, no. 2)

(C) 2003 by The University of Chicago. All rights reserved. 0021-9398/2003/7602-0005\$10.00
We investigate the role of job-match heterogeneity in the CEO labor market. We document a high percentage of CEO turnovers in the early years of tenure as illustrated by the hazard that increases until the fifth year of CEO tenure and then decreases. Evidence suggests that a good match is more likely if the new CEO performs better than the previous CEO. The best matches tend to occur when inside (outside) CEOs follow previous CEOs who quit (are dismissed). Evidence consistent with match theory in the CEO labor market suggests factors that influence the likelihood of observing a good match. 
them. According to match theory, workers who otherwise appear equivalent differ in their productivity because of heterogeneity across firms in the quality of job matches. The implication is that good matches are more productive than bad matches. Of course, labor economists are not the only ones who recognize the importance of matching the "right" worker to the "right" job. Management consultants, for example, emphasize that matching senior people to a job is difficult (Gerstein and Reisman 1983). The finance literature on CEO turnover, however, focuses primarily on monitoring mechanisms of the CEO, including the role of the board of directors (BODs) and blockholders in dismissing poorly performing CEOs, and on the quality of the CEO (e.g., Weisbach 1988; Yermack 1996; Perry 2000). Match theory begins with the notion that there are no good workers or good employers; there are only good matches (Jovanovic 1979a). This is not to imply that monitoring and matching are mutually inconsistent theories. Hermalin and Weisbach (1998), for example, develop a model that incorporates both uncertain match quality and monitoring, but the focus of their model is on the monitoring role of the board. We seek to test some of the implications of job match theory for the CEO labor market. ${ }^{1}$

We do not suggest that all CEO turnovers can be explained by match theory. Economists have developed a variety of models to explain turnover in the labor market, and it is naive to assume that there is one explanation for this phenomenon. However, the usefulness of thinking about CEO turnover in the job match context is to better understand why we observe such a high percentage of CEO turnovers in the early years of tenure. The high percentage of turnovers is significant when one considers the potential disruption of CEO turnover to the firm. If match theory applies to the CEO labor market, then we can determine what factors might help influence the likelihood of observing a good match. Job match theory stresses the importance of the entire CEO succession process, as opposed to focusing solely on how to motivate or monitor CEOs once chosen.

While it can be difficult to differentiate the empirical implications of match theory from other theories of labor market mobility (Garen 1988), we do find evidence that job-match heterogeneity is present in the CEO labor market. First, we find that the hazard increases until the fifth year of CEO tenure and then decreases. This is the shape predicted by Jovanovic's (1979b) model of job match, but it is not the one predicted by other theories of labor market turnover (Farber 1999).

One advantage of studying CEOs is that it affords a proxy for the quality of the job match. Instead of viewing firm performance as a measure of whether or not the CEO is doing a good job, match theory suggests that good matches are characterized by better firm performance than are bad matches. Bishop (1990) takes a similar approach in using supervisor evaluations as a direct measure of match quality. Thus, match theory is an alternative explanation for why firm performance is negatively related to the likelihood of turnover (e.g.,

1. Several recent papers (Hayes and Schaefer 1999; Fee and Hadlock 2000) also mention match theory in relation to CEOs. None of these papers, however, explicitly test matching. 
Warner et al. 1988; Weisbach 1988; Parrino 1997). Another advantage of studying CEOs is the ability to compare two individuals in the same position with the same firm. If turnovers occur because of poor match quality, then good matches should be characterized by firm performance that is higher under the new CEO than under the previous CEO. In fact, we find that a good match is more likely if firm performance is higher under the new CEO than it was under the previous CEO.

Finally, we conduct a more explicit test of match theory. Khurana and Nohria (2000) argue that, independent of ability, firm performance is partially determined by the interaction of the type of previous CEO turnover (quit or dismissal) and the origin of the new CEO (inside or outside hire). For example, outside CEOs are more likely to change the status quo, and the incumbent management will be more responsive to these changes if the previous CEO was dismissed than if the CEO quit. Based on this reasoning, Khurana and Nohria argue that replacing a dismissed CEO with an outside hire will improve firm performance. We interpret this as a matching argument because the productivity of CEOs with similar ability will differ across firms. We find that inside replacements are more likely to be dismissed if the previous CEO was dismissed than if the previous CEO quit.

While our results support the hypothesis that job-match heterogeneity is present in the CEO labor market, we also document differences with typical match theory. We find little evidence that CEOs choose to quit because they are in a bad match. Quits in the CEO labor market arise primarily due to retirements and not because the CEO is leaving for alternative jobs with higher pay. We argue that this follows from the downward rigidity of CEO compensation and the absence of alternative wage offers at the CEO level. Also, the hazard depicts the shape predicted by the job match model, but the peak in the hazard occurs at approximately 5 years of CEO tenure, whereas Farber's (1994) study of the non-CEO labor market finds that the hazard peaks at 3 months. We argue that the CEO labor market and the typical labor market differ significantly in regard to evaluation of performance and cost of turnover.

We begin with a brief exposition of the job match model in Section II. After discussing the applicability of the model to the CEO labor market, we then discuss predictions about CEO turnover that arise from job match theory in Section III. Section IV includes a discussion of our data set and descriptive statistics. We test the job match model using multinomial logit models in Section V. Section VI concludes this article.

\section{Job Match Model and the CEO Labor Market}

Garen (1988) provides a simple description of job match theory. ${ }^{2}$ Job match models assume heterogeneity in the productivity of worker-firm matches and

2. Most models of job match rely on Bayesian techniques and dynamic optimization. See, e.g., Jovanovic (1979a, 1979b); Miller (1984). 
that the quality of these matches is not initially known by either party. Firms and workers learn about the quality of the match early in the worker's tenure, so that only good matches endure because bad matches end quickly. Those with long tenures are in good matches and are less likely to find a better match, and therefore they are less likely to quit. Empirical studies of the relationship between tenure and turnover have met with only limited success in differentiating the importance of job-match heterogeneity from other theories (Garen 1988). ${ }^{3}$ The evidence does suggest, however, that job-match heterogeneity plays a nontrivial role in explaining the relationship between tenure and turnover.

In his seminal paper on matching in labor markets, Jovanovic (1979b) outlines three primary assumptions to set up his model. First, workers differ in their productivity across jobs. This first assumption is the key component of all job match models, and it seems very applicable to the CEO labor market. It seems reasonable, for example, that an executive with a successful history as a "turn-around specialist" would be less successful at a firm that is financially and organizationally sound (e.g., Gerstein and Reisman 1983).

Second, Jovanovic (1979b) assumes that imperfect information exists on both sides of the market about the quality of the job match. In their analysis of CEOs, Gibbons and Murphy (1992) test a model that employs a learning process that is similar to that used by Jovanovic. Gibbons and Murphy, however, focus on learning about the CEO from the firm's perspective. ${ }^{4}$ Job match models assume that the worker is imperfectly informed about match quality as well and this means that the worker may choose to quit because he is in a match of lower than expected quality.

Third, Jovanovic (1979b) assumes that workers and employers negotiate wages on an individual basis. While the assumption of wage negotiation seems realistic on the surface, the actual manner in which CEO compensation is negotiated and the form of this compensation differs from that typically found in the job match literature. Job match models often assume that wages are flexible and that they are negotiated each period (Jovanovic 1979a, 1979b; McLaughlin 1991). Most CEOs are paid a base salary plus bonuses and longterm incentive compensation that is tied to measurable indicators of firm performance (Murphy 1999). According to Murphy, the executive employment contract often includes a guaranteed minimum increase in base salary over the subsequent 5-year period. Not surprisingly, we rarely observe pay cuts in the CEO labor market, suggesting that CEO compensation is downwardly rigid (Hayes and Schaefer 1999). The presence of downwardly rigid wages

3. Human capital theory is another explanation for why turnover decreases with tenure. If some component of the human capital developed on a job is specific to the firm, the worker's productivity and wage increase with tenure at the current firm. Because the accumulated human capital is firm specific, the worker's productivity is likely to be higher at the current firm than at the next best alternative, and they are less likely to quit as tenure increases.

4. Murphy (1986) also tests the learning hypothesis regarding wage determination for CEOs. Similar to Gibbons and Murphy (1992), his focus is on learning about the CEO from the firm's perspective. 
does not mean that the job match model is inappropriate for studying CEOs, but it does have an influence on the predictions of the model.

The presence of downwardly rigid wages has implications for labeling turnovers as quits or dismissals. Given sufficiently flexible wages, job match models have the property that all turnovers arise because workers quit. If realized productivity is less than expected, the firm offers a lower wage. If the lower wage offer is less than the next best alternative, the worker quits. A similar process results in a quit if the worker's productivity is greater than expected. Job match models are often "silent on the division of the total separations into the categories of quits and layoffs" (Jovanovic 1979a, p. 1251). The CEO turnover literature, however, emphasizes the distinction between quits and dismissals.

Is there a theoretical justification for classifying turnovers as quits and dismissals? McLaughlin (1991) takes a novel approach and defines a quit as occurring from a separation following a worker-initiated wage change. A dismissal is a separation following a firm-initiated wage change. Flexible wages result in turnover that is voluntary to both the worker and the firm. If wages are not sufficiently flexible, however, some turnovers are involuntary for either the worker or the firm. Bishop (1990) also argues that firms may have reasons, such as worker morale, for dismissing workers instead of lowering wages. Harris and Weiss (1984) analyze a model with match heterogeneity where they assume risk aversion along with a finite retirement age. They find that one characteristic of the equilibrium of their model is downwardly rigid wages. As a result, not all turnovers will be voluntary for the workers. With this theoretical foundation, we proceed under the assumption that the distinction between quits and dismissals is relevant in the CEO labor market.

There are other aspects of the CEO labor market that differ from the typical labor market depicted using the job match model. First, turnover in job match models occurs because the worker receives an alternative wage offer that exceeds the wage offer of the incumbent firm. This is not descriptive of the CEO labor market, given the small number of firm-to-firm CEO changes observed (Gibbons and Murphy 1992; Hayes and Schaefer 1999). Exiting CEOs almost always exit the CEO labor market, although they may remain on the BODs. Job match models typically abstract from the issue of workers retiring from the labor force by assuming an infinitely lived worker. The workers in our sample, however, are older and nearing retirement. Therefore, we include an age variable in our empirical work.

Second, job match models assume that the quality of the match is learned over time but that the actual value of the match is fixed. For CEOs, the productivity of a given set of skills with a firm may change over time as a firm evolves or as upper management and the BODs changes, or as industry and market conditions change. ${ }^{5}$ Gibbons and Murphy (1992) suggest that 
changes in the firm or its environment may require the BODs to "relearn" about the CEO's ability. Because we do not know when these changes occur within a firm, changing match quality is difficult to account for empirically.

\section{Empirical Implications}

Below we outline some predictions of the job match model. Our primary interest is to better understand the role of job-match heterogeneity in explaining why many CEOs leave the position within a few years. Therefore, we focus most of the empirical analysis on the first years of a CEO's tenure. An advantage of this approach is that it allows us to abstract from the complications that could arise because of changes in match quality.

\section{A. Tenure as $C E O$}

Two empirical regularities of labor markets explained by the job match model are that (1) most new job matches end early and (2) the likelihood of separation decreases with tenure (Farber 1999). Jovanovic's (1979b) model predicts that the hazard initially increases and then decreases. The hazard has this shape because early signals of a poor job match might be ignored "because there is an option value in the match (it might turn out to be very good)" (Farber 1999, p. 2413). Initial separation rates are very low but, as learning occurs, separation rates increase because bad matches are terminated. After this time of weeding out, separation rates decline.

While match theory predicts a hazard that increases and then decreases, agency theory alone makes no obvious prediction regarding tenure and turnover. If learning takes place but there is no job-match heterogeneity, the hazard would monotonically decrease with tenure. Previous research (e.g., Kim 1996; Denis, Denis, and Sarin 1997; Allgood and Farrell 2000) finds conflicting evidence regarding the relation between CEO tenure and turnover. Denis et al. (1997) find no statistically significant relation between tenure and the likelihood of top executive turnover. Allgood and Farrell (2000), however, find that new CEOs (those with 1-3 years of tenure) are more likely to be dismissed than are CEOs with 4-10 years of tenure. Those CEOs with more than 10 years are less likely to be dismissed. ${ }^{6}$

\section{B. Firm Performance}

Perhaps the most accepted empirical regularity in the literature on CEO turnover is that the likelihood of turnover is negatively related to firm performance (Murphy 1999). The typical interpretation of this result is that the BOD dismisses poorly performing CEOs. To the extent that firm performance is a

a successful manager. The response was this: "Some people are better at starting things up, some are better at squeezing the most out of them once they are running, and some are better at fixing them when they go wrong" (p. 33).

6. Kim (1996) also finds that CEOs with more than 10 years of tenure are less likely to be dismissed. 
measure of match quality, poor performance suggests a bad match and, therefore, CEO turnover is more likely. Thus, job match theory also implies a negative relationship between performance and turnover (Bishop 1990).

Data on firm performance under the previous CEO provides an additional test of match theory. If turnover is due to bad matches that have low productivity, then the hiring of a new CEO who is a good match will lead to higher performance than under the previous CEO. That is, the likelihood of early turnover should be lower if the firm performs better under the new CEO than it did under the previous CEO.

\section{The Previous CEOs}

A unique aspect of studying CEOs is the ability to make comparisons across employees holding the same position with the same firm. For example, Parrino (1997) finds a link between firm performance under the previous CEO and who is chosen as the replacement. Specifically, he finds that firms performing poorly relative to the rest of their industry are more likely to hire an outside CEO. Khurana and Nohria (2000) argue that firm performance is affected by the interaction of type of CEO turnover (quit vs. dismissal) and whether the replacement $\mathrm{CEO}$ is an insider or an outsider. The authors argue that the remaining incumbent management will be more responsive to change when the previous CEO was dismissed. In this case, an outside CEO can more effectively institute change, and firm performance will improve. Conversely, an inside replacement will find it difficult to institute change, and firm performance will decrease if the previous CEO was dismissed. Hiring an inside CEO after the previous CEO quits only reinforces the status quo. Khurana and Nohria hypothesize that this succession process will not change firm performance. If an outsider is brought in to replace a voluntarily departing CEO, then "a likely split develops between the internal managers of the firm and the outsider" (p. 11). ${ }^{7}$

This line of reasoning suggests that match quality is partially explained by the interaction of the type of previous CEO turnover and the origin of the new CEO. If this interaction is important in the CEO labor market, we expect inside hires who follow dismissed CEOs to have shorter tenures than inside hires who follow CEOs who quit. We would also expect outside hires to have shorter tenures when following CEOs who quit than when following dismissed CEOs.

\section{Other Unobserved Heterogeneity}

Aside from job-match heterogeneity, heterogeneity in labor markets often refers to workers who may differ in their quit propensity (Garen 1988). One method to control for this unobserved heterogeneity is to include a variable

7. Khurana and Nohria (2000) document improvements in firm performance when the CEO is forced from office and replaced by an outsider and declines in firm performance when a CEO quits or retires and is then replaced by an outsider. 
for the number of jobs the worker has held (Farber 1994). Given that most CEOs are hired from within a firm after years of firm tenure, this type of heterogeneity seems less relevant in the CEO labor market. In addition, few turnovers occur in the CEO labor market due to a CEO leaving for an alternative CEO position. Differences in the quit behavior of outside CEOs, however, may indicate the presence of heterogeneity in the propensity to quit. In the CEO labor market, we argue that unobserved heterogeneity may also arise from firms having a different turnover propensity. That is, a previous CEO with a short tenure may suggest that a firm is more active in inducing turnover. Thus, we use the tenure of the previous CEO as a control for firms that may differ in their turnover propensities.

\section{The Sample}

Unlike many previous studies of CEO turnover, the unit of observation for our analysis is the CEO-firm match. For each job match, our data set contains only one observation. Studies such as those by Warner et al. (1988), Parrino (1997), and DeFond and Park (1999) have multiple observations for each CEO. We treat each match as a single observation because we are interested in the likelihood that a match between the CEO and the firm ends in the first 3 years of tenure and not in the likelihood of turnover in a given CEO year.

\section{A. Description of the Sample}

Since our focus is on analyzing job matches, we initially identify a sample of firms from the Forbes Annual Survey of Executive Compensation and include any firms that appear in Forbes in the period 1981-93. ${ }^{8}$ For each firm, we identify CEO turnovers that occur during the entire 14-year sample period. This process yields a total of 1,524 firms, with 875 firms experiencing 1,388 CEO turnovers prior to any data restrictions. Since the factors influencing a CEO job match may be systematically different between regulated firms and unregulated firms, we eliminate financial institutions and public utilities from the sample. ${ }^{9}$

In addition to identifying CEO turnovers, we must also determine the reason for the turnover. We classify turnovers as dismissals or quits on the basis of information from the Wall Street Journal Index. We categorize as quits all CEO turnovers arising from retirement, normal management succession, or

8. For firms that do not appear in Forbes every year, we analyze proxy statements to the extent that they are available to determine the CEO in office.

9. Smith and Watts (1992) and Gaver and Gaver (1993) provide evidence that the marginal product of the manager as a decision maker in a regulated industry is lower than that of a manager in an unregulated industry. We define regulated industries, consistent with Blackwell and Farrell (1999), as SIC codes 6000-6999 and 4900-4999. 
CEO departure for a prestigious position elsewhere. ${ }^{10}$ After identifying all retirements, we further analyze turnovers identified as retirements for CEOs younger than 62 years of age to determine if the announced retirement is simply a euphemism for a firing. We read the Wall Street Journal article or other press releases relating to the company and the turnover event to determine if any other information is released to suggest a reason for the turnover other than retirement, and we reclassify accordingly. We define dismissal as forced resignations owing to pressure from the board of directors, pressure from outside blockholders, pressure from bank lenders, policy or personality disagreements, demotion, firing, scandal, poor performance, bankruptcy, and reorganization. ${ }^{11}$ When no reason for the turnover is given, we follow Parrino (1997) by using CEO age to categorize the turnover as either a quit or a dismissal. To minimize the likelihood of incorrectly classifying quits as dismissals, we assume that all turnovers for which no reason is given and in which the CEO is younger than 60 years of age are dismissals. Otherwise, they are classified as quits. ${ }^{12}$

We exclude from the sample any turnovers that result from an interim CEO's being replaced. This is done for current and previous CEOs. Interim CEOs often assume the CEO position when an unexpected turnover occurs, such as death or illness. The factors influencing the selection of an interim CEO are likely to be very different from the factors influencing the selection of a permanent CEO. Similarly, we exclude CEOs who leave the sample due to merger, acquisition, bankruptcy, leveraged buyouts, or reorganization of the firm. Again, the factors associated with firms that experience these events are likely to be systematically different from those of surviving firms. Our analysis requires data on the previous $\mathrm{CEO}$; consequently, for a job match to remain in the data set, there must be a previous turnover at the firm in the data set. The previous turnover requirement causes us to exclude founders from the analysis of a job match, since typically founders are the initial CEOs of a firm. However, founders may remain in the data set as previous CEOs. Each observation consists of data on the CEO whose length of tenure is being analyzed, referred to as the current CEO. Each observation also contains data on the CEO immediately preceding the current $\mathrm{CEO}$, referred to as the previous CEO. Further, the current CEO job match must either have terminated by

10. Normal management succession refers to turnovers that evolve over time where the announcement typically suggests that the turnover is part of a planned succession or that an individual is being groomed to take over the CEO position at a specified date. Prestigious appointment elsewhere relates to CEOs leaving one Fortune 500 company for a CEO position at another Fortune 500 company.

11. Our scheme for classifying dismissals and quits is based on the voluntary and forced classifications used by Weisbach (1988), Gilson (1989), Parrino (1997), and Blackwell and Farrell (1999). Death and illness of the CEO are typically classified as voluntary turnovers; however, for purposes of analyzing job matches, these reasons are not synonymous with quits, so these turnovers are excluded from the current CEO job match sample.

12. Denis and Denis (1995) also include "no reason given" as a forced CEO turnover if it involves an external appointment and the departing manager leaves the firm and is not between the ages of 64 and 66. 
1993 or the CEO's tenure must be greater than 3 years in 1993. In addition, firms must be listed on Compustat with complete performance data available for the applicable period. CEO tenure, firm tenure, and age data must be available through Forbes, proxy statements, Dunn and Bradstreet's Reference Book of Corporate Management, or Dunn and Bradstreet's Million Dollar Directory.

The final data set consists of 392 job matches. Of the 392 job matches, $309(79 \%)$ endure beyond 3 years and therefore are classified as good matches. Eighty-three $(21 \%)$ end in the first 3 years of a CEO's tenure and are defined as bad matches. Quits make up 35 of the bad matches, and dismissals account for the remaining 48. Our sample size appears small relative to those of previous studies analyzing the likelihood of CEO turnover in a given year. However, our unit of observation is a job match and not a CEO year. In addition, we require information regarding the previous $\mathrm{CEO}$, which imposes a minimum requirement of one $\mathrm{CEO}$ turnover for each firm in our sample.

We define two performance measures, the return on assets (ROA), measured as the ratio of accounting earnings before interest and taxes to book assets, and stock returns (Return). Both of these measures are industry adjusted. We subtract the median value of the corresponding firm performance measure from the two-digit SIC code industry definition in which the firm participates, as defined by Compustat. We use the two-digit SIC code to industry adjust because Clarke (1989) finds that two-digit SIC codes capture similar general economic characteristics better than three- and four-digit SIC codes.

During the transition year from the previous to the current $\mathrm{CEO}$, firmspecific variables must be assigned to either the current or the previous CEO. We assign any fractional year to the CEO in office at the end of the fiscal year. Firm performance and sales, for example, for the previous CEO reflect that CEO's last full year in office. Performance and sales in the first year of a current CEO may partially reflect the performance of the previous CEO. Ideally, we would assign partial years to CEOs. While monthly stock return data are available, the data for calculating ROA on a monthly basis are not available. As a result, we adopt the same procedure with both performance measures, so that treatment of the transition year is consistent across both performance measures.

For current CEOs, we are interested in individual and firm characteristics from the CEOs' first 3 years in office. When we construct the variables to use in the analysis, we define the variables age, firm tenure, and sales as the CEO's last year or third year in office, whichever comes first. If a current CEO has been in office for more than 3 years, we still use data from his or her first 3 years of CEO tenure. We define Average ROA as the average of the firm's industry-adjusted ROA over, at most, the first 3 years of tenure. For example, if a CEO is dismissed the second year of his or her tenure, average ROA is the average of the first 2 years of tenure. Average return is similarly calculated, but it is for the firm's industry-adjusted stock return. We 
choose average measures of performance to examine the impact of performance over a longer time period. ${ }^{13}$

Average ROA and average return for the previous CEO are for (at most) the last 3 years of the previous CEO's tenure. ${ }^{14}$ We also construct two performance measures that capture the difference in performance of the current CEO and the previous CEO. The variables defined as ROA difference and return difference are the industry-adjusted average performance of the current CEO minus the industry-adjusted average performance of the previous CEO for ROA and stock return, respectively.

\section{B. Descriptive Statistics}

The full-sample descriptive statistics are given in the first two columns of table 1 . The average CEO is about 56 years of age and has a firm tenure of slightly less than 21 years. Approximately $18 \%$ of the current CEOs were hired from outside the firm, where an outside CEO is a CEO that assumes the position within 1 year of joining the firm. The average firm has sales of approximately $\$ 5,500$ million. Average industry-adjusted ROA is approximately $3 \%$, and average industry-adjusted return is about $7.7 \%$. Six percent of the previous CEOs were founders, and the average previous CEO tenure was 10.5 years. Twenty-seven percent of the previous CEOs were dismissed, and $12 \%$ of the previous CEOs left office within 3 years of taking the position. ${ }^{15}$ The average ROA of the previous CEO is about the same as the average ROA of the current CEO, but the average return of the previous CEO is about 270 basis points lower than that of the current CEO (the difference is statistically different from zero at the $6 \%$ level).

Columns 3-8 of table 1 provide the mean and standard deviation of the variables for the different match outcomes of the current CEO. Firm size, age, and firm tenure do not vary much between good and bad matches. Early turnover is more likely with outside CEOs, and performance is lower for the bad match sample. The difference in performance between good and bad matches, however, is driven primarily by the lower performance of CEOs who are dismissed. To the extent that performance proxies for the quality of the match, CEOs who quit early are not worse matches than those that last beyond 3 years. This result is consistent with CEO dismissal arising from the

13. Brickley, Linck, and Coles (1999) define two of their performance measures as average annual industry-adjusted ROA and average annual industry-adjusted stock returns over the CEO's tenure in office or the last 4 years in office, whichever is less. Puffer and Weintrop (1991) use the average ROA over a 5-year period to measure long-run performance.

14. In some cases, we had less than 3 years of data on the previous CEO. If we had 2 years of data, we calculated the 2-year average, and if we had only 1 year we used 1 year. We measure previous performance over a 3-year period since the most recent performance of the CEO is what matters (e.g., Warner et al. 1988; Weisbach 1988).

15. There is an upward bias in our overall dismissal rate due to the exclusion of some turnovers typically classified as voluntary (quits). For example, we exclude turnovers arising from death, illness, or interim status from the sample. 


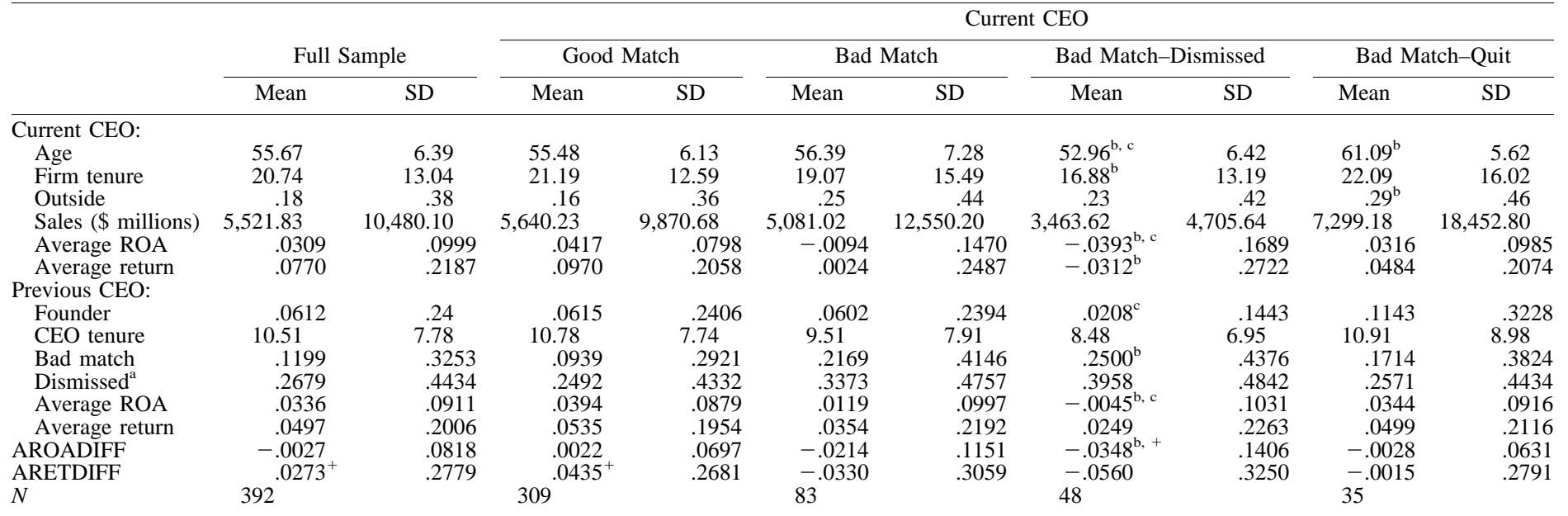

NOTE. - The unit of observation is the CEO-firm match, and the final sample consists of 392 job matches. Three hundred and nine (79\%) of job matches endure beyond 3 years and are classified as good matches. Eighty-three (21\%) of job matches end in the first 3 years of a CEO's tenure and are defined as bad matches. Statistics for age, firm tenure, and sales are for the third year of the CEO's tenure or for his or her last year in office, whichever comes first. Outside identifies CEOs initially hired from outside the firm and is defined as a CEO who assumes the position within 1 year of joining the firm. Founder identifies CEOs who are founders of the firm. CEO tenure is measured as the previous CEO's last year in office. Bad match is defined as a CEO tenure that ends in the first 3 years. Quits represent all CEO turnovers arising from retirement, normal management succession, or those involving the CEO's departure for a prestigious position elsewhere. Dismissals are forced resignations owing to pressure from the board of directors, pressure from outside blockholders, pressure from bank lenders, policy or personality disagreements, demotion, firing, scandal, poor performance, bankruptcy, and reorganization. All turnovers for which no reason is given and the CEO is younger than 60 years of age are classified as dismissals; otherwise, they are classified as quits. Average ROA (return) is the average industry-adjusted ROA (stock return) for, at most, the first (last) 3 years of the current (previous) CEO's tenure. AROADIFF (ARETDIFF) is the average ROA (average return) for the current CEO minus the average ROA (average return) for the previous CEO.

${ }^{a}$ The dismissed category does not restrict the previous CEO sample to bad matches. We include reasons for turnovers for all previous CEO turnovers in our sample, even for those that occur after 3 years of CEO tenure and that are included in the good match category.

The mean value is statistically different from the mean value of the same variable for the good match sample at (at least) the $10 \%$ significance level.

c The mean value is statistically different from the mean value of the same variable for the bad match ends in quit sample at (at least) the $10 \%$ level.

+ Statistically significant at the $10 \%$ level. 
board monitoring and removing poorly performing CEOs. The result is also consistent with job match theory. For a CEO in a bad match to choose to quit, we would expect wages to be downwardly flexible and the CEO to be receiving alternative wage offers. These characteristics do not describe the CEO labor market. Thus, a CEO has little incentive to terminate a bad match, unless it is to retire. As table 1 shows, CEO age is one of the few differences between CEOs who quit (61) and those who are good matches (55).

Firm size is about the same for good matches (\$5,640 million) and bad matches (\$5,081 million), but dismissals occur at firms with lower sales (\$3,464 million), although the differences are not statistically significant. Bishop (1990) finds that matching between firms and workers (not CEOs) is less important at larger firms. Hayes and Schaefer (1999) find evidence that larger firms hire CEOs of higher ability. Mean sales for the data are consistent with the interpretation that, if CEOs at larger firms are more able and matching is less important, early dismissal is less likely at larger firms.

Analyzing variables associated with the previous CEO in table 1, early turnover of the previous CEO is associated with early turnover for the current CEO. Again, the difference between good and bad matches is mostly driven by dismissals of the current CEO. One-fourth of the current CEO dismissals in the first 3 years follow CEOs who were dismissed within 3 years of taking office. This result is consistent with firms having differences in their propensity to induce CEO turnover.

When analyzing changes in firm performance as measured by differences in ROA and return between the current and previous CEO, we find that current CEOs who are bad matches perform worse than the previous CEO. Again, dismissals explain most of this difference. Current CEOs who are good matches experience significant improvements in return relative to the previous CEO. However, unlike the good match sample, CEOs who quit in the first 3 years of tenure do not improve on return. Those CEOs who are good matches with the firm tend to perform better than the previous CEO, suggesting that performance improvement indicates a better job match.

\section{The Hazard}

Match theory suggests that the likelihood of turnover in the next year is conditional on how long a given match has been ongoing. Consider a newly hired CEO. Let $T$ denote the time (measured in years) until this CEO's turnover occurs. Following Lancaster (1990), $T$ is assumed to be a continuous random variable with cumulative distribution function $F(t)=P(T=t)$, survival function $S(t)=1-F(t)=P(T>t)$, and probability density function $f(t)=$ $d F(t) / d t$. Rather than looking at the probability distribution of $T$, match theory would have us look at how prone a CEO is to depart, having worked continuously for $t$ years at the same company, that is, at the conditional distribution and density of $T$ given that $T \geq t$. This conditional density, called the hazard function, is given by $h(t)=f(t) / S(t)$. By comparison, the $f(t) d t$ gives the 


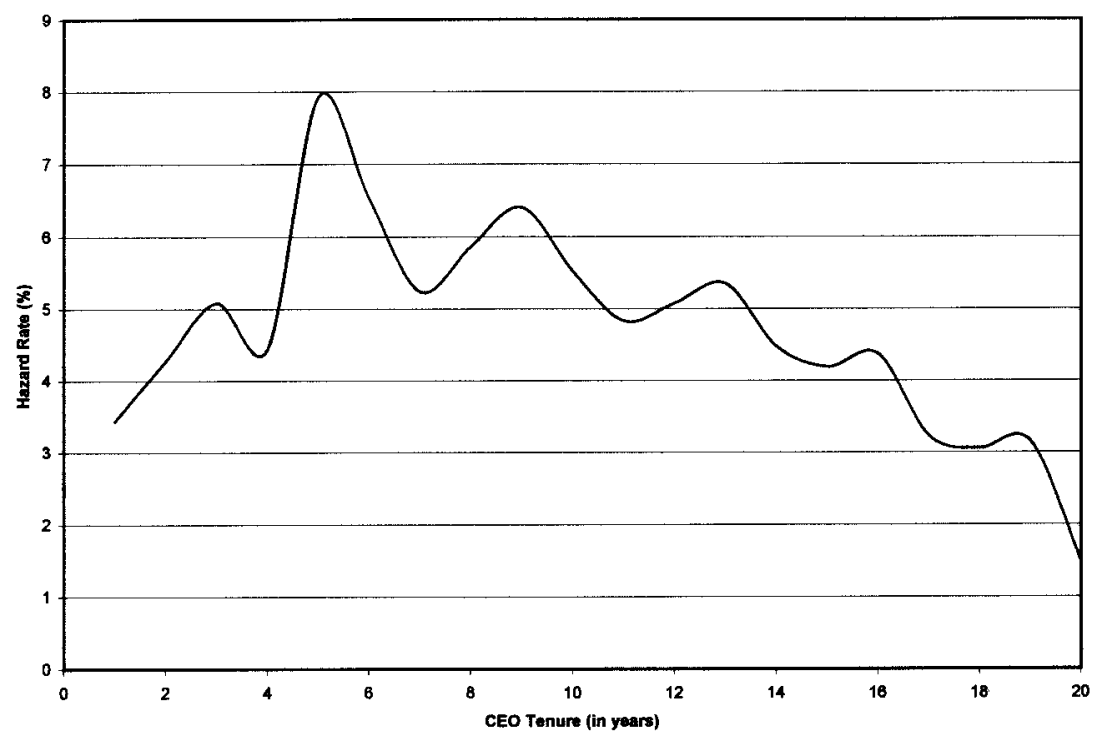

FIG. 1.-The hazard function for 873 CEOs

probability that a newly hired CEO remains with the company for $t$ years and then leaves soon after time $t$. The hazard function and the probability density function are connected via the equation $h(t)=f(t) / S(t)$. Following Kiefer's (1988) estimator (p. 659), we estimate the hazard function by dividing the number of job matches that end at $t$ by the number of matches still ongoing at $t$.

Figure 1 provides the hazard rate for 873 CEOs for each year of tenure. The sample is larger than the 392 observations used for the other statistical analysis because we do not need separate information on the previous CEO and can actually use the previous CEO data to provide information regarding completed spells. In addition, we only need CEO tenure to estimate the hazard function and avoid losing observations due to unavailable data.

Jovanovic (1979b) develops a job match model that predicts a hazard that initially increases and then decreases. Consistent with Jovanovic, figure 1 shows that the hazard initially increases to a peak at 5 years of tenure and decreases thereafter. Farber (1994) studies the labor market mobility of youths using the National Longitudinal Study of Youth (NLSY) and finds that the monthly hazard reaches a peak at 3 months and decreases thereafter. Farber reports a peak monthly hazard of $9.67 \%$, which is slightly larger than the $8 \%$ annual hazard in figure $1 .{ }^{16}$ The difference in the timing of the peaks likely reflects that it takes longer to learn about match quality for CEOs than for

16. Sebora (1996) finds that the hazard has a similar shape for his sample of CEOs. His peak is at approximately $9 \%$ and begins the decline after 4 years of CEO tenure. 
TABLE 2 Frequency of Good Match and Bad Match Outcomes

\begin{tabular}{|c|c|c|c|c|c|}
\hline \multirow{2}{*}{$\begin{array}{l}\text { Current } \\
\text { CEO Status }\end{array}$} & \multirow{2}{*}{$\begin{array}{c}\text { Full } \\
\text { Sample }\end{array}$} & \multicolumn{2}{|c|}{ Previous CEO Quit } & \multicolumn{2}{|c|}{$\begin{array}{l}\text { Previous CEO } \\
\text { Dismissed }\end{array}$} \\
\hline & & Inside & Outside & Inside & Outside \\
\hline Good match & $\begin{array}{r}309 \\
(79)\end{array}$ & $\begin{array}{l}212 \\
(83)\end{array}$ & $\begin{array}{r}20 \\
(67)^{\mathrm{a}}\end{array}$ & $\begin{array}{r}49 \\
(74)\end{array}$ & $\begin{array}{r}28 \\
(72)\end{array}$ \\
\hline Bad match: & & & & & \\
\hline Quit & $\begin{array}{l}35 \\
(9)\end{array}$ & $\begin{array}{l}21 \\
(8)\end{array}$ & $\begin{array}{r}5 \\
(17)\end{array}$ & $\begin{array}{r}4 \\
(6)\end{array}$ & $\begin{array}{r}5 \\
(13)\end{array}$ \\
\hline Dismissed & $\begin{array}{r}48 \\
(12)\end{array}$ & $\begin{array}{l}24 \\
(9)\end{array}$ & $\begin{array}{r}5 \\
(17)\end{array}$ & $\begin{array}{r}13 \\
(20)^{\mathrm{b}}\end{array}$ & $\begin{array}{r}6 \\
(15)\end{array}$ \\
\hline$N$ & 392 & 257 & 30 & 66 & 39 \\
\hline
\end{tabular}

Note. - The final sample consists of 392 job matches. Three hundred and nine (79\%) of the job matches endure beyond 3 years and are classified as good matches. Eighty-three $(21 \%)$ of the job matches end in the first 3 years of a CEO's tenure and are defined as bad matches. Within bad matches, quits represent all CEO turnovers arising from retirement or normal management succession or involving the CEO's departure for a prestigious position elsewhere; dismissals are forced resignations owing to pressure from the board of directors, pressure from outside blockholders, pressure from bank lenders, policy or personality disagreements, demotion, firing, scandal, poor performance, bankruptcy, and reorganization. All turnovers for which no reason is given and the CEO is younger than 60 years of age are classified as dismissals; otherwise, they are classified as quits. Outside identifies CEOs initially hired from outside the firm and is defined as a CEO who assumes the position within 1 year of joining the firm. The number in parentheses is the column percent.

${ }^{a}$ The percentage of outside CEOs is significantly different from the percentage of inside CEOs at the $1 \%$ level.

${ }^{b}$ The percentage of outside CEOs is significantly different from the percentage of inside CEOs at the 5\% level.

the youths depicted in the NLSY and that the cost of turnover for our sample of CEOs is much higher than for the youths making up Farber's non-CEO sample.

\section{An Explicit Test of Matching}

According to Khurana and Nohria (2000), the best matches between a firm and a CEO should be when inside CEOs replace CEOs who quit and when outside CEOs replace dismissed CEOs. Table 2 provides some evidence to support Khurana and Nohria. Table 2 shows the frequency of good and bad matches for current CEOs for four subgroups: inside CEOs replacing CEOs who quit, inside CEOs replacing dismissed CEOs, outside CEOs replacing CEOs who quit, and outside CEOs replacing dismissed CEOs. ${ }^{17}$ The likelihood of an inside CEO being a good match after the previous CEO quit is significantly greater $(83 \%)$ than the likelihood of an outside CEO being a good match $(67 \%)$. We do not find evidence suggesting that outside CEOs who replace dismissed CEOs are more likely to be good matches than insiders who replace dismissed CEOs. Table 2 suggests that there is little difference between the likelihood of a good match when replacing a dismissed CEO with an insider $(74 \%)$ or an outsider $(72 \%)$. Also consistent with match theory, we find that inside CEOs are twice as likely to be dismissed if they replace dismissed CEOs than if they replace CEOs who quit.

17. The distinction between quit and dismissal of the previous CEO is not restricted to turnovers in the first 3 years of CEO tenure. 


\section{Multinomial Logit Results}

The previous section described evidence consistent with the job match model using nonparametric statistical methods. To continue our focus on explaining early CEO turnover, we estimate a multinomial logit model with three possible outcomes for a given observation: good match, bad match that ends with a quit, or bad match that ends with a dismissal. The multinomial logit model maximizes a likelihood function based on the cumulative logistic distribution, and the model is normalized by setting the parameters of the outcome associated with good match to zero. The marginal effects of each variable on the likelihood of a good match are not zero, however. Tables 3 and 4 provide the marginal effects for each variable for all three outcomes. Marginal effects are evaluated at the mean of the overall data.

\section{A. Discussion of Results}

Many of the results in table 3 are consistent with the findings of the simple mean comparisons reported in table 1. For example, older CEOs are more likely to quit early in their tenure and less likely to be dismissed. The signs of the marginal effects of the four current performance variables in table 3 are the same as in table 1 . In panel $\mathrm{A}$ of table 3 , we find that current performance, measured as industry-adjusted average ROA and average return, is positive (negative) and significant for a good match (bad match-dismissal). We also find in panel B of table 3 that both ROA difference and return difference increase the likelihood of a good match. We interpret this as evidence that current good matches tend to improve on the performance of the previous CEO. Similarly, there is a negative and significant relationship between changes in firm performance and the likelihood of observing a bad match that ends with dismissal. In results not reported, we include a variable in the model specifications shown in panel A of table 3 that measures average performance under the previous CEO. Even though panel B of table 3 shows that both difference variables are significant in explaining the likelihood of observing a good match or a bad match that ends in dismissal, the previous CEO performance variables alone are not significant. The insignificance of the previous CEO performance measure suggests that previous good or poor performance by itself is irrelevant in determining subsequent match quality. Instead, the relevant measure of match quality is whether the new CEO performs at least as well as the previous CEO.

In table 1, we show that, while good and bad matches are equally likely to follow a founder, $11 \%$ of the current CEOs who quit follow a previous CEO who was a founder, which is five times greater than for dismissals. Similarly, table 3 shows that a CEO replacing a founder is more likely to quit. These new CEOs reflect the first attempt by these firms to hire a CEO. It is likely that the founder had a role in the selection of the successor and 
remained on the board. ${ }^{18}$ Thus, our results suggest that the founder may not fully relinquish control of the firm when the new CEO takes over and the new CEO is unable to run the firm as he or she wishes. Alternatively, CEOs chosen to follow founders, $75 \%$ of whom are insiders, may be chosen with the implicit understanding that they serve on an interim basis.

In an attempt to control for unobserved heterogeneity, we include in the model a variable that captures whether the previous CEO was a bad match (had a tenure of 3 years or less). Consistent with table 1, table 3 shows a positive relation between previous bad match and the likelihood of a current bad match that ends in dismissal (see cols. 3 and 6 in both panels A and B). We find a negative relation between previous bad match and the likelihood of a current good match, which may simply reflect that firms differ in their propensity to induce turnover. Alternatively, the previous bad match may put pressure on the current CEO to produce rapid results, not just in measurable firm performance but also in terms of providing leadership and stability (Gerstein and Reisman 1983).

Although early turnover of the previous CEO leads to early turnover of the current CEO, the dismissal of the previous CEO does not alter the likelihood of a good match. In addition, table 3 provides no evidence of differences between inside versus outside replacements with respect to the likelihood of observing a good match or a bad match. However, our earlier discussion suggests that the interaction between dismissals and inside versus outside replacements has job match implications (table 2). Table 4 shows the results of reestimating our model but allowing for the interaction of the outside and previous dismissal dummy variables. We define three interaction dummy variables as follows: quit/outside equals one if the previous CEO quits and is replaced by an outsider; dismissed/inside equals one if the previous CEO is dismissed and is replaced by an insider; dismissed/outside equals one if the previous CEO is dismissed and is replaced by an outsider. The omitted category is quit/inside, which defines when the previous CEO quits and is replaced by an insider. Panel A of table 4 reports results measuring performance using industry-adjusted average ROA and return. Panel B of table 4 reports results measuring performance using the ROA and return difference variables.

The interpretation of the results presented in table 4 depends on the performance variable. In particular, none of the interaction variables are significant when firm performance is defined as current average ROA or average return (panel A of table 4). One possible explanation for the lack of significance is that current performance is correlated with previous performance and previous

18. Shivdasani and Yermack (1999) find a high correlation between founder status of the $\mathrm{CEO}$ and the involvement of the CEO in selecting new directors. Similarly, it follows that founders are likely to be involved in selecting their own successor. Seventy-nine percent of the founders in our sample remain on the board after a new CEO is appointed. 
TABLE 3 Multinomial Logit Model of the Likelihood of a Good or Bad Match for Four Measures of Firm Performance

\begin{tabular}{lcccccc}
\hline \multicolumn{7}{c}{ A. Defining Current Performance as Industry-Adjusted Average ROA or Return } \\
\hline
\end{tabular}




\begin{tabular}{|c|c|c|c|c|c|c|}
\hline \multirow[b]{2}{*}{ Variable } & \multicolumn{3}{|c|}{ ROA Difference } & \multicolumn{3}{|c|}{ Return Difference } \\
\hline & Good Match & Bad Match-Quit & Bad Match-Dismissed & Good Match & Bad Match-Quit & Bad Match-Dismissed \\
\hline Constant & $\begin{array}{l}.4593^{* *} \\
(2.61)\end{array}$ & $\begin{array}{l}-.6646^{* *} \\
(5.60)\end{array}$ & $\begin{array}{l}.2053 \\
(1.44)\end{array}$ & $\begin{array}{l}.4511^{* *} \\
(2.55)\end{array}$ & $\begin{array}{l}-.6600^{* *} \\
(5.61)\end{array}$ & $\begin{array}{l}.2089 \\
(1.45)\end{array}$ \\
\hline \multicolumn{7}{|l|}{ Current CEO: } \\
\hline Age & $\begin{array}{l}-.0040 \\
(1.37)\end{array}$ & $\begin{array}{l}.0099 * * \\
(5.57)\end{array}$ & $\begin{array}{l}-.0060 * \\
(2.46)\end{array}$ & $\begin{array}{l}-.0039 \\
(1.34)\end{array}$ & $\begin{array}{l}.0099 * * \\
(5.54)\end{array}$ & $\begin{array}{l}-.0060^{*} \\
(2.45)\end{array}$ \\
\hline Log (sales) & $\begin{array}{l}.0116 \\
(.81)\end{array}$ & $\begin{array}{c}-.0033 \\
(.42)\end{array}$ & $\begin{array}{c}-.0082 \\
(.65)\end{array}$ & $\begin{array}{l}.0121 \\
(.85)\end{array}$ & $\begin{array}{c}-.0032 \\
(.43)\end{array}$ & $\begin{array}{c}-.0088 \\
(.71)\end{array}$ \\
\hline Outside & $\begin{array}{c}-.0066 \\
(.14)\end{array}$ & $\begin{array}{l}.0280 \\
(1.09)\end{array}$ & $\begin{array}{c}-.0214 \\
(.50)\end{array}$ & $\begin{array}{c}-.0279 \\
(.58)\end{array}$ & $\begin{array}{l}.0286 \\
(1.11)\end{array}$ & $\begin{array}{c}-.0007 \\
(.02)\end{array}$ \\
\hline Performance & $\begin{array}{l}.4663^{*} \\
(2.24)\end{array}$ & $\begin{array}{c}-.0456 \\
(.36)\end{array}$ & $\begin{array}{l}-.4207^{* *} \\
(2.51)\end{array}$ & $\begin{array}{l}.1674^{* *} \\
(2.60)\end{array}$ & $\begin{array}{l}-.0434 \\
(1.19)\end{array}$ & $\begin{array}{l}-.1239^{*} \\
(2.24)\end{array}$ \\
\hline Previous CEO: & & & & & & \\
\hline Founder & $\begin{array}{l}.0506 \\
(.51)\end{array}$ & $\begin{array}{l}.0680^{+} \\
(1.87)\end{array}$ & $\begin{array}{l}-.1186 \\
(1.22)\end{array}$ & $\begin{array}{l}.0398 \\
(.40)\end{array}$ & $\begin{array}{l}.071^{* *} \\
(1.97)\end{array}$ & $\begin{array}{l}-.1109 \\
(1.13)\end{array}$ \\
\hline Dismissed & $\begin{array}{c}-.0223 \\
(.56)\end{array}$ & $\begin{array}{c}-.0159 \\
(.65)\end{array}$ & $\begin{array}{l}.0387 \\
(1.13)\end{array}$ & $\begin{array}{c}-.0296 \\
(.73)\end{array}$ & $\begin{array}{l}.0128 \\
(.53)\end{array}$ & $\begin{array}{l}.0424 \\
(1.24)\end{array}$ \\
\hline Bad match & $\begin{array}{l}-.1204^{*} \\
(2.48)\end{array}$ & $\begin{array}{l}.0347 \\
(1.23)\end{array}$ & $\begin{array}{l}.0856 * \\
(2.14)\end{array}$ & $\begin{array}{l}-.1177^{*} \\
(2.43)\end{array}$ & $\begin{array}{l}.0373 \\
(1.35)\end{array}$ & $\begin{array}{l}.0804^{*} \\
(2.00)\end{array}$ \\
\hline $\begin{array}{l}\text { Log-likelihood } \\
\chi^{2} \\
N\end{array}$ & & $\begin{array}{c}-227.27 \\
63.21 \\
392\end{array}$ & & & $\begin{array}{r}-222.16 \\
63.44 \\
392\end{array}$ & \\
\hline
\end{tabular}

NOTE. - The final sample consists of 392 job matches. Three hundred and nine (79\%) job matches endure beyond 3 years and are classified as good matches. Eighty-three (21\%) job matches end in the first 3 years of a CEOs tenure and are defined as bad matches. Of the bad matches, 48 (58\%) are dismissals and 35 (42\%) are quits. The current CEO performance measure is calculated using, at most, the first 3 years of the current CEO's tenure. The previous CEO performance measure is calculated using, at most, the last 3 years of the previous CEO's tenure. Statistics for age and sales are for the third year of the CEO's tenure or for his or her last year in office, whichever comes first. Outside identifies CEOs initially hired from outside the firm and is defined as a CEO who assumes the position within 1 year of joining the firm. Founder identifies CEOs who are founders of the firm. Quits represent all CEO turnovers arising from retirement, normal management succession, or those involving the CEO's departure for a prestigious position elsewhere. Dismissals are forced resignations owing to pressure from the board of directors, pressure from outside blockholders, pressure from bank lenders, policy or personality disagreements, demotion, firing, scandal, poor performance, bankruptcy, and reorganization. All turnovers for which no reason is given and the CEO is younger than 60 years of age are classified as dismissals; otherwise, they are classified as quits.

+ Statistically significant at the $10 \%$ level.

* Statistically significant at the 5\% level.

** Statistically significant at the $1 \%$ level. 
TABLE 4 Multinomial Logit Model of the Likelihood of a Good or Bad Match, Controlling for the Interaction Effect Associated with Whether the Previous CEO Quit or Was Dismissed and Whether the Current CEO Is an Insider or an Outsider

\begin{tabular}{|c|c|c|c|c|c|c|}
\hline \multirow[b]{3}{*}{ Variable } & \multicolumn{6}{|c|}{ A. Defining Current Performance as Industry-Adjusted Average ROA or Return } \\
\hline & \multicolumn{3}{|c|}{ Average ROA } & \multicolumn{3}{|c|}{ Average Return } \\
\hline & Good Match & Bad Match-Quit & Bad Match-Dismissed & Good Match & Bad Match-Quit & Bad Match-Dismissed \\
\hline Constant & $\begin{array}{l}.4125^{*} \\
(2.37)\end{array}$ & $\begin{array}{l}-.6810 * * \\
(5.60)\end{array}$ & $\begin{array}{l}-.2685^{*} \\
(1.98)\end{array}$ & $\begin{array}{l}.4425^{* *} \\
(2.55)\end{array}$ & $\begin{array}{l}-.6615^{* * *} \\
(5.52)\end{array}$ & $\begin{array}{l}.2190^{*} \\
(1.60)\end{array}$ \\
\hline \multicolumn{7}{|l|}{ Current CEO: } \\
\hline Age & $\begin{array}{l}-.0035 \\
(1.25)\end{array}$ & $\begin{array}{l}.0101 * * \\
(5.59)\end{array}$ & $\begin{array}{l}-.0066^{* *} \\
(2.91)\end{array}$ & $\begin{array}{l}-.0035 \\
(1.26)\end{array}$ & $\begin{array}{l}.0099 * * \\
(5.48)\end{array}$ & $\begin{array}{l}-.0064^{* *} \\
(2.80)\end{array}$ \\
\hline Log (sales) & $\begin{array}{l}.0109 \\
(.78)\end{array}$ & $\begin{array}{c}-.0030 \\
(.37)\end{array}$ & $\begin{array}{c}-.0079 \\
(.66)\end{array}$ & $\begin{array}{l}.0077 \\
(.55)\end{array}$ & $\begin{array}{c}-.0032 \\
(.40)\end{array}$ & $\begin{array}{c}-.0046 \\
(.38)\end{array}$ \\
\hline Performance & $\begin{array}{l}.5683^{* *} \\
(3.03)\end{array}$ & $\begin{array}{l}.0688 \\
(.59)\end{array}$ & $\begin{array}{l}-.6371 * * \\
(4.13)\end{array}$ & $\begin{array}{l}.3120 * * \\
(3.52)\end{array}$ & $\begin{array}{l}.0332 \\
. .67)\end{array}$ & $\begin{array}{l}-.2788^{* *} \\
(3.68)\end{array}$ \\
\hline \multicolumn{7}{|l|}{ Previous CEO: } \\
\hline Quit/outside & $\begin{array}{c}-.0386 \\
(.66)\end{array}$ & $\begin{array}{l}.0287 \\
(.85)\end{array}$ & $\begin{array}{l}.0099 \\
(.20)\end{array}$ & $\begin{array}{l}-.0603 \\
(1.00)\end{array}$ & $\begin{array}{l}.0259 \\
(.78)\end{array}$ & $\begin{array}{l}.0344 \\
(.68)\end{array}$ \\
\hline Dismissed/outside & $\begin{array}{l}.0425 \\
(.67)\end{array}$ & $\begin{array}{l}.0194 \\
(.59)\end{array}$ & $\begin{array}{l}-.0619 \\
(1.09)\end{array}$ & $\begin{array}{c}-.0201 \\
(.34)\end{array}$ & $\begin{array}{l}.0132 \\
. .41)\end{array}$ & $\begin{array}{l}.0069 \\
.(14)\end{array}$ \\
\hline Dismissed/inside & -.0272 & -.0153 & .0426 & -.0367 & -.0172 & .0539 \\
\hline & $(.61)$ & $(.49)$ & $(1.25)$ & $(.81)$ & $(.55)$ & $(1.55)$ \\
\hline Founder & .0247 & $.0645^{+}$ & .0892 & .0020 & $.0691^{+}$ & -.0671 \\
\hline & $(.27)$ & $(1.77)$ & $(1.02)$ & $(.02)$ & $(1.87)$ & $(.73)$ \\
\hline Bad match & $-.1168 * *$ & .0335 & $.0833 *$ & $-.1076^{*}$ & .0357 & $.0719^{+}$ \\
\hline Log-likelihood & & -217.99 & & & $\begin{array}{r}(1.25) \\
-222.14\end{array}$ & \\
\hline$\chi^{2}$ & & 81.78 & & & 73.48 & \\
\hline$N$ & & 392 & & & 392 & \\
\hline
\end{tabular}


B. Defining Performance as ROA (Return) Difference Calculated as Average ROA (Return) for Current CEO Minus Average ROA (return) for Previous CEO

\begin{tabular}{|c|c|c|c|c|c|c|}
\hline \multirow[b]{2}{*}{ Variable } & \multicolumn{3}{|c|}{ ROA Difference } & \multicolumn{3}{|c|}{ Return Difference } \\
\hline & Good Match & Bad Match-Quit & Bad Match-Dismissed & Good Match & Bad Match-Quit & Bad Match-Dismissed \\
\hline Constant & $\begin{array}{l}.4754 * * \\
(2.71)\end{array}$ & $\begin{array}{l}-.6655 * * \\
(5.56)\end{array}$ & $\begin{array}{l}.1902 \\
(1.36)\end{array}$ & $\begin{array}{l}.4619 * * \\
(2.62)\end{array}$ & $\begin{array}{l}-.6612 * * \\
(5.57)\end{array}$ & $\begin{array}{l}.1994 \\
(1.40)\end{array}$ \\
\hline \multicolumn{7}{|l|}{ Current CEO: } \\
\hline Age & $\begin{array}{l}-.0042 \\
(1.45)\end{array}$ & $\begin{array}{l}.0099 * * \\
(5.57)\end{array}$ & $\begin{array}{l}-.0058^{*} \\
(2.41)\end{array}$ & $\begin{array}{l}-.0040 \\
(1.39)\end{array}$ & $\begin{array}{l}.0099 * * \\
(5.54)\end{array}$ & $\begin{array}{l}-.0059^{*} \\
(2.44)\end{array}$ \\
\hline Log (sales) & $\begin{array}{l}.0117 \\
(.82)\end{array}$ & $\begin{array}{c}-.0033 \\
(.42)\end{array}$ & $\begin{array}{c}-.0084 \\
(.67)\end{array}$ & $\begin{array}{l}.0122 \\
(.86)\end{array}$ & $\begin{array}{l}-.0032 \\
(.42)\end{array}$ & $\begin{array}{c}-.0089 \\
(.72)\end{array}$ \\
\hline Performance & $\begin{array}{l}.4821 * \\
(2.34)\end{array}$ & $\begin{array}{l}-.0041 \\
(.33)\end{array}$ & $\begin{array}{l}-.4411^{* *} \\
(2.65)\end{array}$ & $\begin{array}{l}.1695^{* *} \\
(2.66)\end{array}$ & $\begin{array}{l}-.0433 \\
(1.18)\end{array}$ & $\begin{array}{l}-.1263^{*} \\
(2.32)\end{array}$ \\
\hline \multicolumn{7}{|l|}{ Previous CEO: } \\
\hline Quit/outside & $\begin{array}{l}-.0699 \\
(1.15)\end{array}$ & $\begin{array}{l}.0261 \\
(.79)\end{array}$ & $\begin{array}{l}.0438 \\
(.84)\end{array}$ & $\begin{array}{l}-.0901 \\
(1.46)\end{array}$ & $\begin{array}{l}.0269 \\
(.81)\end{array}$ & $\begin{array}{l}.0632 \\
(1.19)\end{array}$ \\
\hline Dismissed/outside & $\begin{array}{l}.0056 \\
(.09)\end{array}$ & $\begin{array}{l}.0130 \\
(.40)\end{array}$ & $\begin{array}{c}-.0186 \\
(.34)\end{array}$ & $\begin{array}{c}-.0273 \\
(.45)\end{array}$ & $\begin{array}{l}.0166 \\
(.53)\end{array}$ & $\begin{array}{l}.0107 \\
(.20)\end{array}$ \\
\hline Dismissed/inside & $\begin{array}{l}.0483 \\
(1.05)\end{array}$ & $\begin{array}{c}-.0176 \\
(.56)\end{array}$ & $\begin{array}{l}.0659^{+} \\
(1.82)\end{array}$ & $\begin{array}{l}-.0544 \\
(1.19)\end{array}$ & $\begin{array}{c}-.0148 \\
(.49)\end{array}$ & $\begin{array}{l}.0692^{+} \\
(1.90)\end{array}$ \\
\hline Founder & $\begin{array}{l}.0488 \\
(.50)\end{array}$ & $\begin{array}{l}.0680^{+} \\
(1.85)\end{array}$ & $\begin{array}{l}-.1169 \\
(1.22)\end{array}$ & .0419 & $.0713^{*}$ & -.1132 \\
\hline Bad match & $\begin{array}{l}(.50) \\
-.1255^{* *}\end{array}$ & $\begin{array}{l}(1.85) \\
.0344\end{array}$ & $\begin{array}{l}(1.22) \\
.0911^{*}\end{array}$ & $\begin{array}{l}(.42) \\
-.1214 * *\end{array}$ & $\begin{array}{l}(1.97) \\
.0372\end{array}$ & $\begin{array}{l}(1.16) \\
.0842\end{array}$ \\
\hline & $(2.60)$ & $(1.20)$ & $(2.31)$ & $(2.52)$ & $(1.34)$ & $(2.12)$ \\
\hline $\begin{array}{l}\text { Log-likelihood } \\
\chi^{2}\end{array}$ & & $\begin{array}{r}-225.87 \\
66.02\end{array}$ & & & $\begin{array}{r}-225.87 \\
66.01\end{array}$ & \\
\hline$\hat{N}$ & & 392 & & & 392 & \\
\hline
\end{tabular}

NoTE. - The final sample consists of 392 job matches. Three hundred and nine (79\%) job matches endure beyond 3 years and are classified as good matches. Eighty-three (21\%) job matches end in the first 3 years of a CEO's tenure and are defined as bad matches. Forty-eight (58\%) of the bad matches are dismissals and 35 (42\%) are quits. The current CEO performance measure is calculated using, at most, the first 3 years of the current CEO's tenure. The previous CEO performance measure is calculated using, at most, the last 3 years of the previous CEO's tenure. Statistics for age and sales are for the third year of the CEO's tenure or for his or her last year in office, whichever comes first. Outside identifies CEOs initially hired from outside the firm and is defined as a CEO who assumes the position within 1 year of joining the firm. Founder identifies CEOs who are founders of the firm. Bad match is defined as a CEO tenure that ends in the first 3 years. Quits represent all CEO turnovers arising from retirement or normal management succession or those involving the CEO's departure for a prestigious position elsewhere. Dismissals are forced resignations owing to pressure from the board of directors, pressure from outside blockholders, pressure from bank lenders, policy or personality disagreements, demotion, firing, scandal, poor performance, bankruptcy, and reorganization. All turnovers for which no reason is given and the CEO is younger than 60 years of age are classified as dismissals. Otherwise, they are classified as quits. We define three interaction dummy variables as follows: quit/outside equals one if the previous CEO quits and is replaced by an outsider; dismissed/inside equals one if the previous CEO is dismissed and is replaced by an insider; dismissed/outside equals one if the previous CEO is dismissed and is replaced by an outsider. The omitted category is quit/inside, which defines when the previous CEO quits and is replaced by an insider.

${ }^{+}$Statistically significant at the $10 \%$ level.

* Statistically significant at the $5 \%$ level.

** Statistically significant at the $1 \%$ level. 
dismissal and previous performance are correlated. ${ }^{19}$ The difference variables measure if the current CEO performs better or worse than the previous CEO, which is not correlated with whether or not the previous CEO was dismissed. Panel B of table 4 shows, as predicted, that inside CEOs are more likely to be dismissed if the previous CEO was dismissed than if the previous CEO quit. We also expected a higher likelihood of turnover for outside CEOs following a CEO who quit, but we find no evidence of this. The insignificance of the dismissed/outside variable, however, is consistent with our expectation that the best matches would arise from insiders following CEOs who quit and outsiders following CEOs who are dismissed.

\section{B. Sensitivity Analysis}

To determine the sensitivity of our results to our definition of bad match ( 3 years or less of CEO tenure), we redefine bad match as less than or equal to 4 years of CEO tenure and then reestimate the regressions shown in tables 3 and 4. Our results are largely the same, and in some cases they strengthen the support for job match theory in the CEO labor market. For example, the results reported in tables 3 and 4 show an insignificant relation between sales and the likelihood of observing various match outcomes. In our sensitivity analysis, however, good matches (bad match-dismissal) are positively (negatively) related to sales. The significance of sales is consistent with previous research, which suggests that matching is less important at larger firms (Bishop 1990) and that CEOs tend to be of higher ability at larger firms (Hayes and Schaefer 1999).

When reestimating table 3 , we find that the outside and dismissal dummy variables remain insignificant. However, the table 4 sensitivity results indicate that the variable designating when a previous CEO is dismissed and replaced by an insider remains positive and statistically significant. We also find some evidence that outside CEOs are more likely to be dismissed than inside CEOs if the previous CEO quit, but only when measuring performance using ROA difference $(p=.12)$ and return difference $(p=.06){ }^{20}$

Contrary to what we find in tables 3 and 4 , the sensitivity results indicate that good matches and bad match dismissals are statistically unrelated to previous bad match but that bad matches that end as quits are more likely to occur following a bad match. However, we noted in our previous discussion that the original results may reflect differences in the firms' propensity to induce turnover. The sensitivity results do not support this interpretation and suggest the need for additional research into the relationship between the previous CEO's and the current CEO's tenure.

19. Current average ROA (return) and previous average ROA (return) have a correlation coefficient of .64 (.34) and a $p$-value of .00 (.00). Previous average ROA (return) and dismissal have a correlation coefficient of $-.11(.02)$ and a $p$-value of $.04(.72)$.

20. The sensitivity results also indicate that the likelihood of being a good match decreases with age, which simply reflects the higher likelihood that older CEOs will quit with more years of tenure. 


\section{Conclusion}

Overall, we find evidence that is consistent with observing job-match heterogeneity in the CEO labor market. Consistent with the prediction of Jovanovic's (1979b) model of job match, we find that the hazard initially increases until the fifth year of CEO tenure and then decreases. Match theory also suggests that good matches are characterized by better firm performance than bad matches. We find a positive (negative) relation between firm performance and the likelihood of a firm experiencing a good match (bad match-dismissal). Thus, match theory is an alternative explanation for the empirical regularity that firm performance is inversely related to the likelihood of turnover. We also find evidence that good matches tend to improve on the performance of the previous CEO, whereas CEOs who are bad matches that end in dismissal do not improve on the performance of the previous CEO. Finally, our evidence suggests a link between the reason for the previous CEO's departure and an inside versus outside replacement. Specifically, we find that inside replacements are more likely to be dismissed if the previous CEO was dismissed than if the previous CEO quit. Our results tend to support the idea that the best matches arise from insiders following CEOs who quit and outsiders following CEOs who are dismissed.

Job-match heterogeneity as an explanation for turnover in the CEO labor market does not suggest that incentive problems and monitoring of CEOs are less important. The prevalence of job-match heterogeneity does suggest, however, that more research must be done to further the understanding of what determines the success or failure of a CEO-firm match. As described by Khurana and Nohria (2000), much of the previous research on executive turnover treats the departures of previous CEOs and the origin of new CEOs as independent events. Yet, they argue that these factors are "intimately related processes with respect to their effects on organization outcomes" (p. 3). As Kesner and Sebora (1994) point out, CEO succession is likely to be a traumatic event for a firm since it affects the members of the firm as well as the economic and political climate of the firm. Therefore, the better able a firm is to match the CEO to the firm and avoid early turnover, the more stability is provided to the organization, since a good match is characterized by better performance than a bad match. We believe that we have taken the first step in attempting to analyze CEO turnover in the context of job match theory in order to better understand what factors may increase the likelihood of choosing a CEO that will endure.

\section{References}

Allgood, S., and Farrell, K. A. 2000. The impact of tenure on the firm performance-CEO-turnover relation. Journal of Financial Research 23 (Fall): 373-90.

Bishop, J. H. 1990. Job performance, turnover, and wage growth. Journal of Labor Economics 8 (July): 363-86.

Blackwell, D., and Farrell, K. A. 1999. Changes in compensation and firm performance following CEO turnover. Working paper. Lincoln: University of Nebraska-Lincoln. 
Brickley, J. A.; Linck, J. S.; and Coles, J. L. 1999. What happens to CEOs after they retire? New evidence on career concerns, horizon problems, and CEO incentives. Journal of Financial Economics 52 (June): 341-77.

Clarke, R. N. 1989. SICs as delineators of economic markets. Journal of Business 62 (January): $17-31$.

DeFond, M. L., and Park, C. W. 1999. The effect of competition on CEO turnover. Journal of Accounting and Economics 27 (February): 35-56.

Denis, D. J., and Denis, D. K. 1995. Performance changes following top management dismissals. Journal of Finance 50 (September): 1029-57.

Denis, D. J.; Denis, D. K.; and Sarin, A. 1997. Ownership structure and top executive turnover. Journal of Financial Economics 45 (August): 193-221.

Farber, H. S. 1994. The analysis of interfirm worker mobility. Journal of Labor Economics 12 (October): 554-93.

Farber, H. S. 1999. Mobility and stability: The dynamics of job change in labor markets. In O. Ashenfelter and D. Card (eds.), Handbook of Labor Economics, vol. 3, chap. 37. New York: Elsevier Science.

Fee, C. E., and Hadlock, C. J. 2000. Management turnover and product market competition: Empirical evidence from the U.S. newspaper industry. Journal of Business 73 (April): 205-43.

Garen, J. E. 1988. Empirical studies of the job matching hypothesis. In R. G. Ehrenberg (ed.), Research in Labor Economics, vol. 9, pp. 187-224. Connecticut: JAI Press.

Gaver, J., and Gaver, K. 1993. Additional evidence on the association between the investment opportunity set and corporate financing, dividend and compensation policies. Journal of Accounting and Economics 16 (January): 125-60.

Gerstein, M., and Reisman, H. 1983. Strategic selection: Matching executives to business conditions. Sloan Management Review 24 (Winter): 33-49.

Gibbons, R., and Murphy, K. J. 1992. Optimal incentive contracts in the presence of career concerns: Theory and evidence. Journal of Political Economy 100 (June): 468-505.

Gilson, S. C. 1989. Management turnover and financial distress. Journal of Financial Economics 25 (December): 241-62.

Harris, M., and Weiss, Y. 1984. Job matching with finite horizon and risk aversion. Journal of Political Economy 92 (August): 758-79.

Hayes, R. M., and Schaefer, S. 1999. How much are differences in managerial ability worth? Journal of Accounting and Economics 27 (April): 125-48.

Hermalin, B. E., and Weisbach, M. S. 1998. Endogenously chosen boards of directors and their monitoring of the CEO. American Economic Review 88 (March): 96-118.

Jovanovic, B. 1979a. Firm-specific capital and turnover. Journal of Political Economy 87 (December): $1246-60$

Jovanovic, B. 1979b. Job matching and the theory of turnover. Journal of Political Economy 87 (October): 972-90.

Kesner, I. F., and Sebora, T. C. 1994. Executive succession: Past, present, and future. Journal of Management 20 (Summer): 327-72.

Khurana, R., and Nohria, N. 2000. The performance consequences of CEO turnover. Working paper. Cambridge, Mass.: MIT.

Kiefer, N. M. 1988. Economic duration data and hazard functions. Journal of Economic Literature 26 (June): 646-79.

Kim, Y. 1996. Long-term firm performance and chief executive turnover: An empirical study of the dynamics. Journal of Law, Economics and Organization 12 (October): 480-96.

Lancaster, T. 1990. The econometric analysis of transition data. Cambridge: Cambridge University Press.

Lublin, J. S., and Bannon, L. 2000. Mattel taps Kraft chief as new CEO, ending three-month search. Wall Street Journal May 17, 2000, B1, B4.

McKay, B., and Deogun, N. 1999. After short, stormy tenure, Coke's Ivester to retire. Wall Street Journal (December 7, 1999), pp. B1, B4.

McLaughlin, K. J. 1991. A theory of quits and layoffs with efficient turnover. Journal of Political Economy 99 (February): 1-29.

Miller, R. A. 1984. Job matching and occupational choice. Journal of Political Economy 92 (December): 1086-1120.

Murphy, K. 1986. Incentives, learning, and compensation: A theoretical and empirical investigation of managerial labor contracts. Rand Journal of Economics 17 (Spring): 59-76. 
Murphy, K. 1999. Executive compensation. In O. Ashenfelter and D. Card (eds.), Handbook of Labor Economics, vol. 3, chap. 38. New York: Elsevier Science.

Parrino, R. 1997. CEO turnover and outside succession: A cross-sectional analysis. Journal of Financial Economics 46 (November): 165-97.

Perry, T. 2000. Incentive compensation for outside directors and CEO turnover. Working paper. Tempe: Arizona State University.

Puffer, S. M, and Weintrop, J. B. 1991. Corporate performance and CEO turnover: The role of performance expectation. Administrative Science Quarterly 36 (March): 1-19.

Sebora, T. C., 1996. CEO-board relationship evaluation: An exploratory investigation of the influence of base rate factors. Journal of Managerial Issues 8 (Spring): 54-77.

Shivdasani, A., and Yermack, D. 1999. CEO involvement in the selection of new board members: An empirical analysis. Journal of Finance 54 (October): 1829-53.

Smith, C., and Watts, R. L. 1992. The investment opportunity set and corporate financing dividend and compensation policies. Journal of Financial Economics 32 (December): 263-92.

Warner, J. B.; Watts, R. L.; and Wruck, K. 1988. Stock prices and top management changes. Journal of Financial Economics 20 (January-March): 461-92.

Weisbach, M. S. 1988. Outside directors and CEO turnover. Journal of Financial Economics 20 (January): 431-60.

Yermack, D. 1996. Higher market valuation of companies with a small board of directors. Journal of Financial Economics 40 (February):185-211. 